\title{
Early Investigation of the Impact of Mobile Learning Ethics Student-Generated Activities for STEM Subjects in a Local Malaysian University Context
}

\author{
https://doi.org/10.3991/ijim.v14i05.13359 \\ Shamsul Arrieya Ariffin $(\bowtie)$ \\ Universiti Pendidikan Sultan Idris (UPSI), Perak, Malaysia \\ shamsulefskik.upsi.edu.my \\ Christian Glahn \\ Zhaw IAS Institute of Applied Simulation, Wädenswil Zürich Area, Switzerland \\ Muh Anshar \\ University of Hasanuddin (UNHAS), Makassar, Indonesia \\ Faiz Daud \\ National University Malaysia (UKM), Kuala Lumpur, Malaysia \\ Tee Tze Kiong \\ Universiti Tun Hussein Onn Malaysia (UTHM), Johore, Malaysia \\ Nurul Hazlina Noordin \\ Universiti Malaysia Pahang (UMP), Pahang, Malaysia \\ Amirrudin Kamsin \\ University Malaya (UM), Kuala Lumpur, Malaysia
}

\begin{abstract}
Mobile learning is fairly new in the local context, particularly for STEM subjects in Malaysia universities. However, this raises the issue of the ethics of mobile technology. With the advancement of mobile technologies few studies have been conducted for mobile ethics in student-generated activities. The aim of this research is to investigate the impact of mobile learning studentgenerated activities ethics in Malaysia. The methodology used in this research is largely qualitative with students from a local university in Malaysia. This novel study developed early themes that sign post factors for mobile ethics in studentgenerated activities in a Malaysian university context for STEM subjects.
\end{abstract}

Keywords-Mobile learning, student-generated activities, mobile ethics

\section{Introduction}

Many concerns have been raised about the ethics on using mobile technologies in the classroom $[1,11,29]$. These concerns include the misuse of mobile phones, cheat- 
ing in exams, and security issues $[10,11]$. As students increasingly own and use mobile devices, such as mobile phones, smart phones and tablets [21], educational institutions need to develop concepts and strategies for integrating the students' mobile devices into their practice. Such concepts and strategies require a good understanding of the teaching ethics related to mobile devices from the perspectives on all stakeholders in an institution. However, this understanding appears to be underdeveloped with respect to student perspectives in different countries worldwide [8].

The present study is framed by the national guidelines of the Ministry of Education that prohibit Malaysian students to bring any mobile device into the classroom [11]. The national guidelines are partially motivated by the potential of mobile devices to interrupt class activities if these devices are unmanaged or their use lacks proper guidelines $[4,5]$. This situation creates a tension between the mobile-technology-rich experiences outside educational institutions and the mobile-technology-poor experiences on the inside. Such tension appears to contribute to a systemic misalignment of the students' academic performances across subjects [31].

Small scale studies help to overcome such tensions by developing culturally and educationally meaningful strategies for integrating mobile technologies into the practice of educational institutions. This paper presents such a study and seeks to contribute to creating awareness about mobile ethics in student-generated activities for STEM in higher education in Malaysia [11].

\subsection{Mobile learning}

There are about 6 billion mobile phone users worldwide [19]. Mobile learning is a key driver to broadening access to education $[2,3]$ by enabling learners to pursue their studies according to their own scheduled time, anytime, and anywhere [27]. More advanced approaches to mobile learning allow for authentic learning experiences $[6,22,25]$. For instance, this approach enables learning that happens transversely in terms of time and place [27], or anchors learning activities to contexts [16]. Additionally, mobile phones enable the transfer of, and access to information in order to build on their specific skills and knowledge [3, 16].

In Malaysia, the phenomenon of using mobile devices for learning in education is increasing day-by-day [7, 9, 25]. Many institutions of higher learning have witnessed the evolvement of mobile learning since the early 2000's [24].

\subsection{Science, technology, engineering and mathematics (STEM)}

STEM education refers to learning and teaching in the fields of science, technology, engineering, and mathematics. The concept covers educational approaches across all grade levels from pre-school to post-doctorate and extends to non-formal and informal learning [18, 23].STEM is the purposeful integration of the various disciplines as one unit for solving real-world problems that involve some or all four disciplines science, technology, engineering, and mathematics[14, 32]. 


\subsection{Student-generated activities}

Student-generated activities refers to learning activities created and organized by the learners $[10,13]$. The concept opposes predesigned learning activities by lecturers or learning designers. In the context of STEM education, this approach is inspired by the pedagogy of experiential learning [15, 24]. In Malaysia, the process for studentgenerated activities for STEM in universities consists of active experience, reflection, abstract conceptualization, and new strategies [8].

Previous studies indicated that student-generated activities positively influence the quality of learning $[18,8,10]$. As a side effect, student-generated activities can counter a lack of local and contextualized learning resources $[2,3,10]$.

\subsection{Limited research on mobile ethics policies}

Regardless of the alarms pertaining the usage of mobile devices for mobile learning [20], there is a lack research concerning the ethics of mobile learning and the use of mobile devices in the classroom [17], this is despite the increased concerns of educators about the educational use of mobile technologies in Asia [33]. This lack of empirical data has been previously raised [3] and motivates the present study. The article confirms the data from the UNESCO report on Mobile Learning [30]. Thus the research question to this study will be:"What are the current mobile learning policies for learning STEM at a Malaysian local university?"

\section{$2 \quad$ Method}

This study focuses on student attitudes towards educational ethics after the students created mobile learning activities in Sultan Idris Education University in Malaysia. The study involves focus group discussions. This qualitative approach [28] emphasizes on understanding the students' perspectives on creating their own learning resources in a science curriculum [26]. In this study the students bring their own personal mobile devices (BYOD) for creating educational mobile learning content [4,5]. The data is analyzed using a thematic analysis approach [28, 12].

\subsection{Participants}

The study included 30 participants from the STEM Subjects biology, chemistry, computer science, mathematics, or robotics background. The participants were selected on the same principles as in a previous study and performed different task based on their subject [4]. The distribution of the participants across the subjects is shown in Table 1. At the time of the study, the participants were between twenty and twentyfive years old. 
Table 1. Students Focus Groups

\begin{tabular}{|c|l|l|l|c|l|}
\hline \multicolumn{1}{|c|}{ Course } & Code & \multicolumn{1}{c|}{ Subject } & FG & \multicolumn{1}{c|}{ Time } \\
\hline 1 & Software Engineering & FG1 & Discrete Math (FT1) & 5 & 65 mins \\
\hline 2 & loftware Engineering & FG2 & Computer Organization (FT2) & 5 & 53 mins \\
\hline 3 & lhemistry & FG3 & Biology (FT3) & 7 & 75 mins \\
\hline 4 & Robotics & FG4 & Robotics (FT4) & 6 & 80 mins \\
\hline 5 & lomputer Design & FG5 & Design (FT5) & 7 & 150 mins \\
\hline & Total & & & 30 & \\
\hline
\end{tabular}

Note: 'FG' = Focus Group, for example FG1 = Focus Group 1

\subsection{Focus group discussions}

This study builds on data from focus group discussions for approximately one to two hours. However, there is no restriction for the length because the discussion is voluntarily upon the groups. Focus group discussions were chosen for data collection from the students, because Malaysian students tend to be more responsive when they discuss in groups rather than being interviewed individually.

In this study, semi-structured open-ended questions were deployed, such as:

a) What do you understand about ethics in mobile learning student-generated activities?

b) Describe your experience using mobile devices for learning during studentgenerated activities?

c) What are some examples of ethics in mobile learning student-generated activities?

\section{$3 \quad$ Findings}

The research indicates five themes emerged from the preliminary focus group discussions about mobile ethics for student generated activities as shown in table 2.

Table 2. Emerging Themes from Preliminary Focus Group Discussions

\begin{tabular}{|c|l|c|c|c|c|c|c|}
\hline \multirow{2}{*}{ Generated Themes } & \multicolumn{3}{c|}{ Numbers of Nvivo Statements } & \multirow{2}{*}{ Total } \\
\cline { 3 - 7 } & & FG1 & FG2 & FG3 & FG4 & FG5 & \\
\hline 1. & Plagiarism Concern & $\mathbf{3}$ & & 7 & & 7 & $\mathbf{1 7}$ \\
\hline 2. & Self-regulated ethics & & 5 & & & $\mathbf{3}$ & $\mathbf{8}$ \\
\hline 3. & Politeness in using language in the video & & & & & $\mathbf{3}$ & $\mathbf{3}$ \\
\hline 4. & Security & & & & 4 & & 4 \\
\hline 5. & Generation differences & $\mathbf{3}$ & & & & & $\mathbf{3}$ \\
\hline & Total & $\mathbf{6}$ & $\mathbf{5}$ & $\mathbf{7}$ & $\mathbf{4}$ & $\mathbf{1 3}$ & \\
\hline
\end{tabular}

The themes in descending order are: plagiarism concern with a total of 17 statements: FG1 has 3; FG3 has 7; and FG5 has 7. This is followed by self-regulated ethics with a total of 8 statements: FG2 has 5; and FG5 has 3. For security theme has a total of 4 statements for FG4. Next, politeness in using language in the video theme has a 
total of 3 statements for FG5 and generation differences theme has a total of 3 statements for FG1.

Meanwhile the focus group with descending order is FG5with a total of 13 statements and 3 themes: plagiarism concern has 7 statements; self-regulated ethics has 3 statements; and politeness in using language in the video theme has 3 statements. Next, FG3 has a total of 7 statements with plagiarism concern. FG1 has a total of 6 statements with two themes: plagiarism concern has 3; and generation difference has 3 statements. FG2 has a total of 5 statements which is the self-regulated ethics theme. Finally, FG4 has a total of 4 statements which is the security theme.

\subsection{Mobile ethics impact}

In this study, the emerging themes from the data are the mobile ethics impact resulted from student generated activities as shown in Table 2.

Plagiarism concern: The participants expressed their concern about the ownership of the content. Some examples are:

"We must not plagiarize but if we use something as a reference and we upgrade then it is not plagiarism because we upgrade it to something new. So that is the awareness that I get for multimedia content." (FG3)

"For example, we take a picture or video we need copyright from the source, otherwise if we take a video from YouTube, we must have permission from the owner. Apart of that is, we don't plagiarize somebody's work, for example, such as a logo in a video produced for our multimedia content, that's all." (FG5)

Self-regulated ethics: Self-regulation is also being practiced by participants as stressed by many. For example:

"Use in the right way and do not do illegal things, such as take a picture whenever we like." (FG2)

"We must not use offensive language because the video is published to public, so we need to control our own language." (FG5)

Politeness in using language recording the video: During the recording there was some concern about politeness and awareness concerning the language being used. For example:

"The implementation of ethics in the video production is a guide not to offend any authorities." (FG5)

Security: Concern about the security such as the usage of a pen drive for mobile devices was also highlighted by participants. Some examples:

"Laptops are one of the devices that can easily get infected by a virus, so we have to be cautious with our pen drive so it does not transfer the virus to other laptops." (FG4)

"All laptops are sensitive mobile devices as they can easily get infected by a virus if we are not careful, for example, when a pen drive is inserted, sometimes the laptop will get corrupted and is easily attacked by viruses. We have to format them two or three times." (FG4) 
Generation Difference: The participants stressed the differences between the younger and older generation:

"In terms of knowledge do you think we are better than our parents? I don't think so, in terms of knowledge they are probably much better than us even though we have many advantages in terms of using the so-called mobile devices, but do we really fully utilize it in good way, I'm not sure." (FG1)

\section{Discussion}

The participants agreed that the significance of ethics for student-generated activities should be emphasized in the local context, particularly for STEM subjects [3]. Self-regulation is one of the most important criteria for mobile ethics [10]. In order to implement mobile learning ethics' policies in the local universities, awareness about the mobile ethics should be highlighted. In Malaysia, there are limited policies for mobile learning [7]. In this study, there were ethical considerations about using mobile devices.

The limitations of this study are due to only a local university participated with the study. Thus, this study needs to have more cases to be generalized to other different universities. Additionally, involving more participants from different universities can increase better understanding for the research particularly on mobile ethics in student generated activities.

The implications for further research need to be to implement to different local context particularly from more participants in Malaysian universities. This will further provide a better in-depth perspective particularly for the mobile ethics in student generated activities for local Malaysian context.

\section{Conclusion}

The contribution of this research is the insights from the themes concerning how the factors of mobile ethics impacting mobile learning were demonstrated through student-generated activities for STEM subjects in a local university context. This could lead to a greater awareness of mobile ethics to improve STEM subjects in the Malaysian university context [3]. Additionally, the study answered to the research question that the mobile ethics is not implemented at the local context [30] rather than being a self-regulated practice. Mobile learning policies, such as ethics or mobile learning implementation guidelines, could be introduced, particularly in learning STEM in the local Malaysian context. Thus, future studies will be expanded to several local universities or even to other countries in order understand mobile ethics for student-generated activities. 


\section{$6 \quad$ References}

[1] Andrews, T., Dyson, L. E., \& Wishart, J. (2015). Advancing ethics frameworks and scenario-based learning to support educational research into mobile learning. International Journal of Research \& Method in Education, 38(3), 320-334. https://doi.org/10.1080/1743 727x.2015.1026252

[2] Ariffin, S.A., Dyson, L.E., \& Hoskins-McKenzie, D. (2012). Content is King: Malaysian Industry Experts' Point of View on Local Content for Mobile Phones. Journal of Mobile Technologies, Knowledge \& Society, 2012 (2012), 1-9. https://doi.org/10.5171/2012.73 $\underline{8493}$

[3] Ariffin, S. A. (2018a). Towards a Smart Educational Environment Framework for mobile learning in a Malaysian context, In Proceedings of the 4th International Conference on Human-Computer Interaction and User Experience in Indonesia, CHIuXiD'18 (pp. 74-81). ACM. https://doi.org/10.1145/3205946.3205957

[4] Ariffin, S. A., Yatim, M. H. M., Zaibon, S. B., Ali, A. Z. M., Ibrahim, A. B., Sidek, S. F., \&Muttalib, M. F. H. A. (2018b). An Investigation of Student Experience of STEM Mobile Learning in a Local Malaysian University. In World Conference on Mobile and Contextual Learning (pp. 36-50).

[5] Ariffin, S. A., Sidek, S. F., \&Mutalib, M. F. H. (2018c). A Preliminary Investigation of Malaysian Student's Daily Use of Mobile Devices as Potential Tools for STEM in a Local University Context. International Journal of Network \& Mobile Technologies, 12(2). 1-12 https://doi.org/10.3991/ijim.v12i2.8015

[6] Ariffin, S. A., Ismail, A., Yatim, M. H., \&Sidek, S. F. (2018d). An Assessment of Culturally Appropriate Design: A Malaysian University Context. International Journal of Interactive Mobile Technologies, 12(2), 1-8 https://doi.org/10.3991/ijim.v12i2.8014

[7] Ariffin, S. A. (2017, April). Needs and Potentials for Studying Local Malaysian Culture through Mobile Learning. In Proceedings of the 3rd International Conference on HumanComputer Interaction and User Experience in Indonesia (pp. 60-66). ACM. https://doi. org/10.1145/3077343.3077352

[8] Ariffin, S. A. (2016a). Academics' Perspectives on the Challenges and Opportunities for Student-Generated Mobile Content in Malaysia. International Journal of Mobile and Blended Learning (IJMBL), 8(3), 49-64. https://doi.org/10.4018/ijmbl.2016070104

[9] Ariffin, S. A. (2016b). Investigating the Daily Use of Mobile Phones as Tools to Enhance mobile learning for Local Cultural Subjects in the Context of Malaysian Universities. In Mobile and Blended Learning Innovations for Improved Learning Outcomes (pp. 143158). IGI Global. https://doi.org/10.4018/978-1-5225-0359-0.ch008

[10] Ariffin S. A (2014). The Contribution of mobile learning to the Study of Local Culture in the Malaysian University Context, PhD dissertation, Faculty of Engineering and Information Technology, University of Technology Sydney, Sydney, Australia

[11] Ariffin, S. A., \& Dyson, L. E. (2013). Mobile learning in Malaysian universities: Local ethical considerations for mobile phone use. Transactions on Mobile Learning, 2, 15-19.

[12] Braun, V.\& Clarke, V. (2006). Using thematic analysis in psychology. Qualitative Research in Psychology 3(2), pp. 77-101. https://doi.org/10.1191/1478088706qp063oa

[13] Chin, C. (2002). Student-Generated Questions: Encouraging Inquisitive Minds in Learning Science. Teaching and Learning, 23 (1), pp 59-77.

[14] Crompton, H., \& Traxler, J. (Eds.). (2016). Mobile Learning and STEM: Case Studies in Practice. Routledge.

[15] Dewey, J. 1938. Experience and Education, Macmillan, New York USA. 
[16] De Jong, T., Specht, M., \& Koper, R. (2008). Contextualised media for learning. Journal of Educational Technology \& Society, 11(2), 41-53

[17] Dyson, L. E., Wishart, J., \& Andrews, T. (2017). Ethical Issues Surrounding the Adoption of Mobile Learning in the Asia-Pacific Region. In Mobile Learning in Higher Education in the Asia-Pacific Region (pp. 45-65). Springer, Singapore https://doi.org/10.1007/978-98110-4944-6_3

[18] Dyson, L.E. (2012). Student-generated mobile learning: A shift in the educational paradigm for the 21st century. anzMLearn Transactions on Mobile Learning, 1(1), 5-19

[19] Gonzalez, H. B., \& Kuenzi, J. J. (2012, August). Science, technology, engineering, and mathematics (STEM) education: A primer. Congressional Research Service. In Library of Congress.

[20] Gupta, N., Garg, S., \& Arora, K. (2016). Pattern of mobile phone usage and its effects on psychological health, sleep, and academic performance in students of a medical university. National Journal of Physiology, Pharmacy \& Pharmacology, 6(2), 132-139. https://doi.org/ 10.5455/njppp.2016.6.0311201599

[21] Hussin, S., Manap, M.R., Amir, Z. \&Krish, P. Mobile learning readiness among Malaysian students at higher learning institutes. Asian Social Science 8, 12 (2012), 276-283. https:// doi.org/10.5539/ass.v8n12p276

[22] Kolb, D.A. (1984). Experiential learning: experience as the source of learning and development, 1 edn, Prentice Hall, New Jersey USA, pp. 1-256.

[23] Kukulska-Hulme, A., \& Traxler, J. (2007). Designing for mobile and wireless learning. Rethinking pedagogy for a digital age: Designing and delivering e-learning, 180-192. https://doi.org/10.4324/9781351252805-12

[24] Labov, J. B., Reid, A. H., \& Yamamoto, K. R. (2010). Integrated biology and undergraduate science education: a new biology education for the twenty-first century? CBE-Life Sciences Education, 9(1), 10-16. https://doi.org/10.1187/cbe.09-12-0092

[25] Nordin, N. M., Embi, M. A., Norman, H., \& Panah, E. (2017). A Historical Review of Mobile Learning Research in Malaysia and Its Implications for Malaysia and the AsiaPacific Region. In Mobile Learning in Higher Education in the Asia-Pacific Region (pp. 137-150). Springer, Singapore. https://doi.org/10.1007/978-981-10-4944-6 7

[26] Pittman, K. M. (1999). Student-generated analogies: Another way of knowing? Journal of Research in Science Teaching: The Official Journal of the National Association for Research in Science Teaching, 36(1), 1-22. https://doi.org/10.1002/(sici)10982736(199901) 36:1<1::aid-tea2>3.0.co;2-2

[27] Sharples, M., Taylor, J., \&Vavoula, G. (2010). A theory of learning for the mobile age. In Medienbildung in neuen Kulturräumen (pp. 87-99). VS Verlag für Sozialwissenschaften. https://doi.org/10.1007/978-3-531-92133-4_6

[28] Silverman, D. (2013). Doing qualitative research: A practical handbook. London: SAGE Publications Limited.

[29] Spinello, R.A. (2003). Case studies in information technology ethics. $2^{\text {nd }}$ ed. Upper Saddle River, NJ: Prentice Hall.

[30] So, H.J. (2012). Turning on mobile learning in Asia: Illustrative initiatives and policy implications. In S. Vosloo\& M. West (Eds.), Policy focus: UNESCO working paper series on mobile learning (Vol. 1). Paris: UNESCO.

[31] Tømte, C., \&Hatlevik, O. E. (2011). Gender-differences in self-efficacy ICT related to various ICT-user profiles in Finland and Norway. How do self-efficacy, gender and ICT-user profiles relate to findings from PISA 2006. Computers \& Education, 57(1), 1416-1424. https://doi.org/10.1016/j.compedu.2010.12.011 
[32] Traxler, J., \&Crompton, H. (2016). Mobile Learning and STEM: Case Studies in Practice, Routledge, https://doi.org/10.4324/9781315745831

[33] Wishart, J. (2018). Ethical considerations in the incorporation of mobile and ubiquitous technologies into teaching and learning in educational contexts. In Mobile and Ubiquitous Learning (pp. 81-93). Springer, Singapore. https://doi.org/10.1007/978-981-10-6144-8_5

\section{Acknowledgement}

The authors would like to express their appreciation to all the participants. The appreciation extends to the Ministry of Higher Education Malaysia via UPSI, which provided the FRGS grant code: 2017-0074-107-02, and the grant from GUP-2017-061 for the involvement of medical students from UKM in this research.

\section{Authors}

Shamsul Arrieya Ariffin, Faculty of Art Computing and Creative Industry is with Universiti Pendidikan Sultan Idris (UPSI), Tanjong Malim, Perak, Malaysia.

Christian Glahn is from Zhaw IAS Institute of Applied Simulation, Wädenswil Zürich Area, Switzerland. glanias@gmail.com

Muh Anshar, Faculty of Electrical Engineering is with University of Hasanuddin (UNHAS), Makassar, Indonesia. sharmuh79@gmail.com

Faiz Daud, Faculty of Medicine, is with National University Malaysia (UKM), Cheras, Kuala Lumpur, Malaysia. drfaizdaud@gmail.com

Tee Tze Kiong from Department of Professional Education, is with Universiti Tun Hussein Onn Malaysia (UTHM), BatuPahat, Johore, Malaysia. tktee@uthm.edu.my

Nurul Hazlina Noordin from The Department of Industry and Community Network (ICoN), is with Universiti Malaysia Pahang (UMP), Pekan, Pahang, Malaysia. hazlina@ump.edu.my

Amirrudin Kamsin from Department of Computer System \& Technology is with University Malaya (UM), Kuala Lumpur, Malaysia. amir@um.edu.my

Article submitted 2020-02-13. Resubmitted 2020-03-04. Final acceptance 2020-03-04. Final version published as submitted by the authors. 